\title{
Institutional determinants of deliberative interaction
}

\author{
CLAUDIA LANDWEHR ${ }^{1}$ AND KATHARINA HOLZINGER ${ }^{2}$ \\ ${ }^{1}$ Schumpeter Fellow, Department of Political Science, Johann Wolfgang Goethe-Universität, \\ D-60054 Frankfurt am Main, Germany \\ ${ }^{2}$ Chair of International Relations and Conflict Management, University of Constance, Box 90, \\ D-78457 Konstanz, Germany
}

\begin{abstract}
A central assumption of deliberative theory is that political preferences are endogenous to decision-making processes in which they are transformed by communicative interaction. We identify discursiveness and coordination of interaction as central determinants of preference change and develop a typology of political modes of interaction that affect the likelihood of preference change differently. These properties are in turn influenced by institutional characteristics of the fora in which communicative interaction takes place. To illustrate our approach empirically we present a comparative analysis of two extreme modes of interaction, 'debate' and 'deliberation', providing a case study of a parliamentary debate and a citizen conference on the same conflict: the import of embryonic stem cells in Germany. We assess the discursiveness and coordination as well as the amount of preference transformation in both forums.
\end{abstract}

Keywords: deliberative democracy; communicative interaction; arguing; bargaining; preference transformation

\section{Introduction}

A central assumption of deliberative theory is that political preferences are formed and transformed by communicative interaction. ${ }^{1}$ For example, della Porta defines: 'we have deliberative democracy when ... a communicative process based on reason ... is able to transform individual preferences and reach decisions oriented to the public good' (della Porta, 2005: 340). If a discourse is sufficiently powerfree and inclusive, then preferences are transformed more readily. The preferences evolving from the discourse are expected to be better informed; and they are ethical rather than subjective in Harsanyi's (1955) sense. Moreover, they are

\footnotetext{
* E-mail: Landwehr@em.uni-frankfurt.de

${ }^{1}$ Probably the first to use the term 'deliberative democracy' was J.M. Bessette (1980). For recent accounts of deliberative democracy, see, for example Gutmann and Thompson (1996), Bohman (1996), Dryzek (2000), or Goodin (2003), as well as collections by Bohman and Rehg (1997), Elster (1998), Macedo (1999) and Fishkin and Laslett (2003).
} 
supposed to have converged towards a consensus, the content of which is likely to be more just than the result of preference aggregation without deliberation.

However, several elements in this central assumption are not sufficiently theorized and so far lack empirical evidence. One shortcoming of deliberative theory is that it lacks a theory of preference transformation that could explain why and how communication affects preferences. ${ }^{2}$ Another, in some ways related, problem is that while deliberation is advocated as a mode of interaction, there is little consensus on how it could be institutionalized. ${ }^{3}$ The central problem of empirical research on deliberation is that there is no agreement on how the theory could be operationalized nor on what hypotheses would need to be confirmed in order to provide support for its central assumptions (see Neblo, 2005; Mutz, 2008; Thompson, 2008). It thus seems necessary to develop explicit hypotheses about the effects of institutional parameters on modes of interaction as well as about the effect of modes of interaction on preference formation and transformation.

The empirical question of how communicative interaction affects actor preferences and decisions is of interest beyond the focus of deliberative theory. It is of relevance for questions of institutional design: how, where, and when should political decisions be prepared and taken? It matters for our understanding of political actors' motivation: how far are political goals internal or external to decision-making processes? To what extent are actors driven by material selfinterest, institutional logics of appropriateness (March and Olsen, 1989), or moral reasons? And finally, the question must play a role wherever we seek to understand concrete decisions and policy choices of political forums: to what extent are they determined in advance by the given preference constellation and to what extent were they enabled and driven by an exchange of arguments and information?

While the overarching research programme of deliberative democracy is concerned with the relationship between institutions, communication, and actors' motivation, our paper can only address one part of it, providing what Mutz advocates as 'middlerange' theory-building and research (Mutz, 2008: 522) and Thompson as a 'disaggregated approach' to empirical research on deliberative democracy (Thompson, 2008: 509). First, we will develop hypotheses on how the institutional properties of forums affect modes of interaction realized in them and thus their likelihood of being deliberative. Second, comparing a non-deliberative and a deliberative forum, we will attempt to assess whether the deliberative forum does indeed make preference transformation more likely than the non-deliberative forum.

The theoretical section of the paper starts with a clarification of the concepts of preference and preference transformation and identifies two requirements for communicative interaction to be effective: discursiveness and coordinativeness.

${ }^{2}$ A pioneer in empirical work on preference transformation was James Fishkin (1991). For more recent research, see Hansen (2004).

${ }^{3}$ On the use of participatory methods to institutionalize deliberative democracy, see a handbook by Gastil and Levine (2005). 
Crossing these properties in a matrix yields four ideal-typical modes of interaction. Two institutional contexts are identified as being, respectively, maximally favourable and maximally averse to preference transformation: one is represented by the model of the consensus conference and the other by a typical plenary debate in the legislature of parliamentary systems in which legislative work is mostly done by committees (second section).

The empirical part of the paper presents a comparative analysis of a parliamentary debate and a consensus conference on the same conflict: the import of embryonic stem (ES) cells in Germany. This particular conflict is interesting because political parties and social groups in Germany were deeply divided over the issue, which would not fit into a single left-right dimension (third section). Next, we briefly introduce the case selection principle and our methods to measure discursiveness, coordinativeness, and preference transformation (fourth section), before the analysis proceeds in two steps. First, a speech act analysis (SAA) of transcripts from both forums is undertaken to assess to what extent interaction was discursive and coordinative - and thus deliberative. Second, the occurrence and direction of preference changes in the two forums is assessed (fifth section).

\section{Theory and hypothesis: a typology of modes of interaction}

The theory of deliberative democracy asserts that preferences are endogenous to political discourses and decision-making procedures, in which they are formed and transformed. The giving and taking of reasons at the heart of deliberative democracy can only drive political decisions if, as Habermas points out, reasons are also motives (Habermas, 1994: 188), or as we put it, if they influence actors' policy preferences.

In our understanding, political preferences are defined by policy options and express an attitude of comparative evaluation with both cognitive and volitional components. The volitional component concerns the desirability of states of the world, the cognitive one the instrumentality of options to bring these about. For the purpose of analysing political decision-making, it makes sense to regard preferences as being defined over policy options.

For the cognitive component of policy preferences, the case for transformability is straightforward: cognitive attitudes (beliefs or acceptances) would lose their purpose if they were not responsive to new evidence and arguments. Most political conflicts are at least in part due to conflicting beliefs about the world. ${ }^{4}$ More controversial and more interesting is the transformation of the volitional component of preferences. It seems that goals, values, and interests cannot possibly change constantly. If a goal were not to remain stable and effective to an actor's choices for at least a considerable amount of time, there would be no point in adopting it at all. And if norms and values changed all the time, they could not serve as general

\footnotetext{
${ }^{4}$ See Landwehr (2009: Ch. 1). On the distinction between beliefs and acceptances, see Cohen (1989).
} 
principles to guide action. If deliberation is to make preferences more otherregarding and just, however, volitional attitudes must be transformable as well. Deliberative democrats assume that they can be transformed by exposition to new practical reasons. We assume that their transformation is most likely to be caused by a new weighting and aggregation of competing reasons (i.e. conflicting goals, norms, and values). ${ }^{5}$

Moving from individual decision-making to the challenges of communicative interaction and collective decision-making, the link between the two levels is the requirement for justification, that is, for giving reasons. Individuals enter into discourses to assess and improve the justification of their preferences, and justificatory discourses form and transform preferences. According to Habermas, pressures for justification and reciprocity are necessarily exerted in communicative interaction, as 'reaching understanding is the inherent telos of human speech' (Habermas, 1984: 287). However, even given that there are pressures for justification inherent in language use itself, not every kind of communication enables and enhances preference transformation equally. Rather, there are contextual parameters that determine whether preferences and the reasons they are based on are challenged, assessed, and reconsidered, and thus affect the probability that the cognitive or volitional premises of preferences will be transformed. Such contextual parameters determine different modes of interaction that are more or less favourable for preference changes.

There are two properties of communicative interaction which we see as central determinants of the probability of preference change in the context of political decision-making: discursiveness and coordinativeness. In what follows, we define these two properties, as well as the four ideal-type modes of interaction that result from their combination.

\section{Discursiveness}

We define communicative interaction as discursive when it is both public and dialogical. The level of discursiveness increases with the degree of publicity and dialogical communication. 'Discursiveness' of interaction enables and promotes the exchange and assessment of acceptances about the world and practical reasons.

Publicity is important to ensure the generality and transferability of reasons. It does not necessarily have to be mass-media publicity, what matters is a logic of publicity: that interaction is in principle accessible to outsiders and that what is being said is in principle said for everyone to hear. As Elster $(1995,1998)$ and Chambers $(2004,2005)$ have pointed out, there tend to be trade-offs between the publicity and quality of a discourse, so that in many cases we are confronted with the choice between the second-best options of public, but rhetorical (and

\footnotetext{
${ }^{5}$ On practical reasons as motivations for action, see Brandom (1994). On conflicts between practical reasons, see Steedman and Krause (1986) and Richardson (1994). On practical reasons and preference formation, see Landwehr (2009: Ch. 1).
} 
non-dialogical) arguing and non-public (but dialogical) bargaining. We agree that there are obstacles to realizing interaction that is both public and dialogical. However, if the audience addressed has to be large only in principle, but not necessarily empirically, for interaction to be defined as public, discursiveness is not by necessity exceptional.

Regarding the dialogical qualities of interaction, it is important that assertions can and will be challenged and that every hearer gets a chance to become a speaker. Habermas has drawn a distinction between the listener and the hearer where the listener is confined to a passive role in which he can make up his mind and keep a discursive score on what the speaker says, but cannot undertake commitments himself, ask questions, or challenge the speaker's commitments. The hearer, by contrast, has to take a stance on what is being said: if he does not challenge the speaker's commitments, he implicitly agrees with them and accepts them as premises for further reasoning and decision (see Habermas, 2000). When participants are hearers rather than listeners, they are committed to the outcomes of interaction. Although our notion of discursiveness thus draws on Habermas, it is much less demanding than his concept: we do not require the institutional setting to be inclusive and power-free, and we do not demand participants to be truthful.

\section{Coordinativeness}

Interaction is defined as coordinative where there is a strong requirement to come to a collectively binding decision or where the decision rule requires substantial agreement and exit is impossible. Both pressures serve to coordinate individual action plans. The level of coordinativeness increases with the pressure to take a decision and with the decision rule. Coordinative pressure can arise externally, for example through formal rules and the official tasks of a collective political actor, but it may also arise internally by the aspiration of participants to produce a joint output or to reach consensual agreement.

The first indicator of external pressures for coordinativeness is the presence of a formal requirement to take a collectively binding decision, as is usually the case in constitutional collective decision-making bodies. Time pressure is also important here. Many deliberative forums lack this strong pressure to produce a joint outcome, as they can at most provide a policy recommendation. In case of deep conflicts, incentives to reach an agreement are thus weak, and exits and dissenting votes common. However, even where a formal or political requirement to come to a decision is lacking, participants in a communicative forum may aspire to reach an agreement and as a group internally define the goal of their interaction as that of arriving at a joint position.

The second indicator is the decision rule of the forum, or the way agreement and disagreement are dealt with. Where no decision rule is specified, decisions tend to become impossible for a lack of coordinative incentives. Majority rule motivates coalition-building, albeit not across ideological boundaries or conflicting interests. The outcome will therefore coordinate the action plans of a majority, but not all participants and thus be less inclusive. Where consensus is an 
explicit goal or unanimity is enforced, coordinativeness is higher than in the first two cases. Here, compromises between conflicting interests, competing goals or values become necessary - compromise being understood as agreement enabled by concessions rather than persuasion.

Combining the two factors of discursiveness and coordinativeness yields the matrix of modes of political interaction shown in Table $1 .^{6}$ Each cell idealtypically defines one mode of interaction. Most real instances of interaction are probably best placed somewhere in between these ideal-types, but these are of considerable value as reference points for comparison. The labels used for the ideal-types - discussion, deliberation, debate, and bargaining - are common both in natural language use and in political science. It may therefore be important to stress that we use our own definitions, which may differ from definitions found elsewhere in the literature. Nonetheless, our definitions overlap to a considerable extent with the meanings of the respective terms in common language.

\section{Debate}

Debate is defined as both non-coordinative and non-discursive. It is non-discursive because it is non-dialogical, although public: it is a sequence of monologues rather than a dialogue, and assertions cannot immediately be challenged. Thus, the listeners are not committed to the results of interaction. The Encyclopedia Britannica defines debate as the 'formal, oral confrontation between two individuals, teams or groups who present arguments to support opposing sides of a question, generally according to a set form or procedure' (emphasis added). The French origin, 'débattre', meaning 'to defeat, to strike down', (figuratively) points to the goal of participants in a debate. Groups are pre-defined, and they present rather than exchange arguments. Examples of institutionalizations are debating clubs, TV talk shows with politicians from all parties, or plenary debates in majoritarian parliamentary systems. While plenary debates in parliaments presuppose many coordinative efforts and compromises within parties and coalitions, the debate itself does not require further coordination. Instead, it serves the majority to defend a decision that has been taken in advance and the minority to attack it. Although a public debate, whether in parliament or in the media, may affect listeners' preferences, preference changes among the interlocutors are unlikely. Consequently, the debate is the mode of interaction that is most unfavourable for preference transformation.

\section{Discussion}

Discussion as a mode of interaction is defined here as discursive but not coordinative in its logic. The Encyclopedia Britannica refers to this as the 'consideration of a question in open and usually informal debate' (emphasis added). The Latin

\footnotetext{
${ }^{6}$ These ideal-typical modes of interaction are discussed in more detail in Landwehr (2009).
} 
Table 1. Ideal-type modes of interaction

\begin{tabular}{lll}
\hline \hline & Non-coordinative & Coordinative \\
\hline Discursive & Discussion & Deliberation \\
Non-discursive & Debate & Bargaining \\
\hline \hline
\end{tabular}

origin of the word points to more aggressive, adversary forms of interaction: 'discutio', meaning 'first, to batter; second, to shake off; third, to assess, to interrogate'. The last meaning highlights pressures for justification and discursiveness, which are also central to our definition here, according to which discussion is ideal-typically both public and dialogical. In political forums, the role of participants in a discussion is often defined as 'expert' and the goal of interaction is one of information. Discussions typically lack an explicit decision rule: if experts do not arrive at a consensus through communication alone (which they are often expected to, but typically do not), they should have no material interest in reaching unanimity by means of compromises. While discussion can improve the justification of acceptances and enable the pooling of information, preference transformation is an unlikely outcome: the lack of coordinative incentives prevents compromises between practical reasons.

\section{Bargaining}

Bargaining is defined as non-discursive; it is, while dialogical, non-public in its logic. At the same time, it is a coordinative mode of interaction. Bargaining occurs in constellations that imply the possibility of benefits from cooperation. There are thus high internal incentives to reach an agreement that serves both parties; if no agreement on a course of action is achieved, participants will not be able to increase their utility beyond the status quo. Consequently, strong material interests in compromises and coordination may ideal-typically be assumed. Often, there are also formal external requirements to come to a decision, such as in industrial relations. Finally, it is a unanimous mode of decision-making. The definition the Encyclopedia Britannica gives for bargaining is very much in keeping with ours: 'first, to negotiate over the terms of a purchase, agreement, or contract: haggle; second, to come to terms: agree'. The second meaning clearly refers to the coordinativeness of interaction.

While bargaining aims at compromises, the discursive qualities of interaction are ideal-typically low. Usually, bargaining processes are not accessible to everyone and thus non-public in our definition. As a consequence, there are less pressures to justify one's preferences by reference to acceptances and practical reasons, and these will not be questioned, assessed, or reconsidered. ${ }^{7}$ Rather, participants seek to

\footnotetext{
${ }^{7}$ Empirically, actors seem to feel a necessity to give reasons for their preferences and positions also under conditions of non-publicity and even if reasons are private rather than generalizable and transferable, as research by Holzinger (2004) and Naurin (2007) has shown.
} 
maximize their own preferences under the constraints of the other participants' preferences. The most likely outcome of bargaining is that actors have the same preferences post-interaction that they had pre-interaction, although they may agree on a course of action to be taken. Coordination is desired and compromise is possible and will be achieved through dialogical interaction, but preferences need not be changed. ${ }^{8}$ The ideal-typical kind of bargaining we have in mind here comes close to what has been described as 'distributive bargaining' and is contrasted with integrative bargaining (cf. Scharpf, 1997: Ch. 6).

\section{Deliberation}

Deliberation is defined as the only type of interaction that is both discursive and coordinative. The Encyclopedia Britannica describes it as 'a discussion and consideration by a group of persons of the reasons for and against a measure' (emphasis added). This description comes very close to our own idea, as does the meaning of its Latin origin 'deliberare': 'to weigh, to consider, to reflect'. Compared to some explications found in the extensive literature on deliberative democracy, our definition of deliberation is rather parsimonious, but does not contradict the more demanding meanings of Habermas and others (such as Steiner et al., 2005). We talk of deliberation if interaction is public and dialogical, and thus discursive, and if it is characterized by strong coordinative incentives. These coordinative incentives may be due to external pressures or internal aspirations, which, for example, arise from the fact that participants feel a responsibility to produce a joint result. We thus understand deliberation as essentially decision-related interaction (cf. Thompson, 2008: 502). Coordination plays a different role here than in contexts of non-decision, where participants are not bound by the results of interaction. Where deliberation is successful, justificatory and coordinative pressures can improve factual information and enable compromises between fundamental values and the convergence of preferences. It is thus the mode of interaction that may be expected to be most favourable to preference transformation.

According to our definition, however, deliberation does not ensure that the resulting preference changes are desirable from a normative point of view. Inequalities, biases, and manipulatory strategies may well change preferences for the worse rather than for the better (see, e.g. Sunstein, 2003). Moreover, where coordinativeness is externally enforced through a unanimity requirement, deliberation may in fact protect the status quo. In these cases, majority votes may be more legitimate as an approximation of democratic consensus. ${ }^{9}$ A normative assessment of preference change would, we think, also presuppose a normative and more demanding definition of deliberation that includes aspects such as

\footnotetext{
${ }^{8}$ Ideal-typical settings of bargaining are, however, rare in political decision-making processes as these refer almost necessarily to ethical preferences that need to be justified.

${ }^{9}$ We thank an anonymous reviewer for this point.
} 
equality and authenticity. We prefer to use a less demanding definition of deliberation here and to leave this question open for future research.

From the above considerations, we derive the following hypothesis:

HYPOTHESIS 1: The more discursive and coordinative communicative interaction is, the more preference change is likely to occur.

The discursiveness and the coordinativeness of forums in which communicative interaction takes place are determined by their institutional characteristics and their political function.

\section{The case: the decision over the import of ES cells in Germany}

As an empirical illustration we selected the case of legislation on the import of ES cells in Germany. This case can be seen as typical of a political decision on a collectively binding norm (and not only a collective decision on the distribution of private gains), which may be seen as a precondition of democratic deliberation. The case is a clear instance of a value conflict, but also implies a conflict of interests. Therefore, volitional and cognitive components of preferences and arguing as well as bargaining can be expected to play a role. We give an overview of the conflict and of the various communicative forums that dealt with it before we proceed to describe our methodology.

In August 2000, Oliver Brüstle, a neurobiologist at the University of Bonn, submitted a proposal for a research project using imported ES cells to the German Research Foundation. German law forbade the production and killing of embryos for research purposes but did not regulate the import of ES cells. On the one hand, ES cells do not count as embryos according to the legal definition. On the other hand, the isolation of stem cells inevitably leads to the death of the embryo, which means that importing stem cells could encourage a practice illegal in Germany. Researchers thus found themselves in a situation of legal uncertainty. While there was wide consensus in the political sphere that such uncertainty must be abolished, fundamental conflicts surrounded the issue of how these new opportunities for biomedical research could and should be restricted.

Oliver Brüstle's application for funding a research project using imported ES-cells sparked a lively debate in the media and raised politicians' awareness about the fact that further regulation was required. On 24 March 2001, the German parliament (Bundestag) established a 'Study Commission on Ethics and Law of Modern Medicine', consisting of 13 Members of Parliament and 13 experts named by the parliamentary parties. A month later, the government instituted the second expert commission. The 'National Ethics Council' was composed of experts and interest group representatives who were appointed by the Chancellor. In contrast to the Study Commission, the National Ethics Council was directly responsible to the government. The first task the Ethics Council was charged with was the drafting of a report on the question of ES cell imports. 
On 5 July 2001, the question of ES cell imports first appeared on the parliamentary agenda. With the governmental majority, the Bundestag passed a motion submitted by the Social Democrats (Sozialdemokratische Partei Deutschlands, SPD) and the Green Party demanding a 'conscientious and comprehensive assessment of the import and research with ES cells' before the Bundestag again dealt with the question that same year. ${ }^{10}$ In November 2001, the two expert commissions presented their reports. Neither was consensual, but each pointed out alternative options.

During the autumn and winter months, an inter-factional group of members of parliament (MPs) developed the eventually successful compromise motion. The second inter-factional group drafted a motion for a complete ban, the third group a motion to permit the imports. ${ }^{11}$ On 30 January 2002, the Bundestag discussed the three motions in plenum. The debate was celebrated as one of the parliament's finest hours, and the quality and atmosphere of argumentation were widely appreciated. The procedure chosen differed from normal legislation in that the requirement to vote according to party policy (the whip) was officially suspended, allowing and demanding MPs to vote according to their conscience. Two roll call votes were taken, the first on all three motions, the second on the motions for a compromise and a ban, which had gained the highest number of votes. In the second vote, the compromise motion was approved.

Subsequently, the interfactional group around the compromise motion drafted an explicit bill in informal meetings. Compared to the motion approved by the Bundestag on 30 January, the bill specifies a number of points only vaguely stated in the motion. This formulation of the explicit legislative bill on the basis of an unspecified motion was at least in part enabled by bargaining between conflicting groups and interests. On 25 April 2002, the Bundestag held the second reading on the issue of ES cell imports, in which the bill was approved.

In 2003, an interdisciplinary team from the Max-Delbrück Center for Molecular Medicine and the Research Center Jülich organized a citizen conference on stem cell research. Inspired by the Danish consensus conference model (see Joss and Durant, 1995), the initiators of the citizen conference hoped to enrich the debate with points of view taken from the citizens' 'lifeworld', which are often neglected in public debates, and to picture the variety of opinions on the topic. ${ }^{12}$

In order to set up a group that was representative of the population at large, 14,000 persons living in the cities of Berlin, Bernau, and Nauen were selected randomly from a telephone register and contacted by mail with information about the topic and goals of the conference and asked to reply if they were interested in participation. From the 400 or so people who replied two groups of 20 people were drawn according to sociodemographic criteria such as age, gender, and occupation. One group was the actual

10 BT-Drs. 14/6551. The motion brought by the opposition CDU/CSU (BT-Drs. 14/6314) essentially demanded the same, but named different reasons for a moratorium.

11 14/8101 (compromise.), 14/8102 (ban), and 14/8103 (permission), all BT-Drs.

12 The procedure, results, and evaluation of the citizen conference are documented in Tannert and Wiedemann (2004). 
citizen group, the other a control group for evaluation. Among the 20 citizens selected, 17 turned up for the first weekend meeting, of which five dropped out before the second meeting. The eight female and nine male participants were aged between 18 and 62 (equally distributed over age groups). Eight were Protestants, two Catholics, one Muslim, and six without denomination. Regarding their occupations, it is striking that the only member with low formal education - an unemployed painter - dropped out while the majority of remaining participants were either students or held professional jobs. ${ }^{13}$ Despite the sophisticated selection procedure, both the actual citizen group and the similarly composed control group thus suffered from a lack of representativeness due to processes of self-selection (cf. Burow and Kühnemuth, 2004).

In December 2003, the first meeting of the citizen conference was called; the second and third meeting took place in January and March 2004. The focus on the first weekend was on introduction, information, and organization, the second was devoted to the preparation of an expert hearing that took place on the third weekend. Interaction took place both in the plenum and in smaller groups, using methods such as mind maps and flip charts. The second weekend meeting also included a meeting and discussion with an ethicist, who was invited at the citizens' explicit demand. On the second day of the final weekend, the citizen vote was decided on and written. In March 2004, a press conference was organized and the citizen report handed over to the president of the German Bundestag. Although the citizen conference itself took place too late to have any impact on policy development or parliamentary decisions, it is an interesting subject of analysis for the comparison of different types of forums and modes of interaction within them.

Reconsidering the ideal-typical modes of interaction outlined in the third section, each mode seems to have been institutionalized in at least one of the forums involved in the decision over the import of ES cells. Table 2 assigns the empirical forums to the respective types of interaction.

\section{Methodology: case selection and measurement concepts}

While the theory of deliberative democracy was first developed as a normative theory of democratic legitimacy by authors like Habermas (1994), Dryzek (2000), Bohman (1996), or Gutmann and Thompson (1996), its empirical assumptions are increasingly being investigated (see Mutz, 2008; Thompson, 2008). In fact, the number of researchers engaged in empirical research on deliberative democracy now seems to be larger than that of normative theorists, resulting both in a rapid proliferation of the theory beyond its original field and an increasing diversity of approaches (for an overview, see Bächtiger et al., 2009).

\footnotetext{
13 Three members were students, two lawyers, two medical technicians (one in training), one a web designer, one a deputy manager of a building centre, one an alternative practioner, one a learning therapist, one a tradesman, one a sales representative, two retired (one police superintendent, one engineer), one a civil servant and one an unemployed former painter.
} 
Table 2. Forums in the ES-cell debate

\begin{tabular}{lll}
\hline \hline & Non-coordinative & Coordinative \\
\hline Discursive & Discussion & Deliberation \\
& Parliamentary Study Commission, & Citizen conference on stem cells \\
& National Ethics Council & \\
Non-discursive & Debate & Bargaining \\
& Bundestag plenum & Drafting of bill \\
\hline \hline
\end{tabular}

As Mutz notes, many empirical tests of deliberative democracy are in fact examinations of whether political discussion in a particular context meets the standards to be considered deliberative (Mutz, 2008: 528) - including the 'Discourse Quality Index' developed by Steiner et al. (2005) (Steenbergen et al., 2003; Bächtiger, 2005) and Holzinger's (2001, 2004, 2005) use of speech act theory to distinguish arguing from bargaining. Other researchers have focused on the effects of deliberation on actors' opinions, preferences, or action plans (Fishkin, 1991; Niemeyer, 2002; Hansen, 2004; Schneiderhan and Khan, 2008).

In this paper, we try to address both process and outcome, in an analysis of forums dealing with the same political conflict. However, this is only possible by factoring out many important aspects of deliberative theory. Our analysis of interaction does not capture properties such as equality of participants, mutual respect, power-free exchange of arguments, or the quality of argumentation. Our measurement of preference transformation tells us nothing about whether the preference changes we observe were desirable or not, that is whether preferences were transformed for the better or worse. We thus view our contribution as a 'middle-range' contribution to deliberative hypotheses (cf. Mutz, 2008: 530) that gains part of its relevance only in comparison with other researchers' work.

\section{Data and case selection}

The aim of the analysis of the different forums in which the stem cell conflict was addressed is to illustrate the effects of institutional factors on modes of interaction and of interaction on actor preferences. We thus seek a first confirmation or invalidation of the respective hypothesis. Accordingly, the central questions in the empirical analysis are the following:

1. To what extent is the interaction that takes place in the forums discursive and coordinative? Do the institutional and behavioural properties serve to realize a mode of interaction that comes close to the respective ideal-type? (explanatory variables).

2. To what extent does preference transformation occur? (dependant variable).

Data on the institutional properties of a forum, such as its composition, its task or the decision rule applying to it, which serve as indicators of external coordinativeness, are 
comparatively easy to collect. The discursiveness and internal coordinativeness of a forum, as well as the degree and direction of preference transformation are somewhat more difficult to measure. In an ideal case, transcripts of the interaction and direct observation are available to assess discursiveness and internal coordinativeness, along with interviews or questionnaires to assess preference transformation.

From the forums dealing with the question of ES cells two are chosen for closer analysis: the parliamentary debate and the citizen conference. These are extreme cases, as they represent the extreme values of the typology, that is our explanatory variable. The debate, according to our theory, rules preference transformation out, while the citizen conference as an institutionalization of deliberation is most favourable to it. This corresponds to the most dissimilar case study design that allows us to draw conclusions on the institutional variable, while the type of conflict is kept constant. For these two forums satisfactory data to address all three questions were available: we have transcripts of the interaction, interviews, questionnaires, observation reports, and data on the voting behaviour as revealed preference.

As the forums fulfil different functions in the decision-making process and have different objectives, their comparability may be called into question. While the plenary debate constitutes the final moment of a decision-making process that was prepared in a parliamentary study commission and the National Ethics Council, in party meetings and the public sphere, the consensus conference was supposed to mirror this entire process in miniature. Asking how institutional characteristics affect interaction and thereby the likelihood of preference change, we nevertheless think that the comparison of two such (institutionally) different forums makes sense: we want to show how different forums produce different modes of interaction because they have different functions.

Obviously, a single case cannot satisfy the standards of an academic survey as a general confirmation of hypotheses. Nevertheless, causal inferences are possible on the basis of a comparison of two observations varying on the explanatory factor. For generalization, however, the investigation of more cases is necessary.

\section{The method of speech act analysis}

In order to assess the discursiveness of interaction, we undertook a SAA of the transcripts. Developed as an approach to linguistic pragmatics by Austin (2002 [1962]) and Searle (1979), speech act theory was introduced to social theory when Habermas drew on it in his 'Theory of Communicative Action' (Habermas, 1984). Austin and Searle pointed out that in making an utterance in a conversation, a speaker carries out an action, the speech act. SAA builds on this theory and was first employed in a political science context by Holzinger (2001) and, in a somewhat different way, taken up by Nullmeier (2003). Our analysis here is based on Holzinger's approach and develops it further.

An empirical analysis of speech acts undertaken in an actual conversation can focus either on the act of predication, that is on what is actually being said and 
how it is said, on the illocutionary level, that is on what actors do in saying what they say, or on the perlocutionary level, that is on what effects speech acts have on other participants. Take the following example:

\section{〈If we don't stop global warming, many species are going to die out.〉}

At the level of predication, this sentence establishes a causal relationship between global warming and the extinction of species. At the illocutionary level, the sentence, if uttered by a speaker, constitutes an assertion, or more precisely, a warning. At the perlocutionary level, finally, the warning might lead the hearer to believe in the causal relationship and to draw personal consequences. SAA as undertaken here focuses on the illocutionary level and asks what illocutionary acts reveal about the mode of interaction in a given situation. Table 3 lists arguing and bargaining speech acts as employed in the subsequent analysis.

Bargaining is non-public not only in that it often takes place behind closed doors but also in that the reasons employed are private and non-transferable rather than public and transferable. Bargaining speech acts such as to DEMAND, PROMISE, Or THREATEN point to private resources and interests rather than generalizable reasons or arguments. The presence of bargaining speech acts thus indicates a kind of non-publicity with regard to actors' reasons. The absence of bargaining speech acts may be regarded as an indicator for the publicity of reasons and arguments, which is one of the two requirements for discursiveness. The absence of arguing speech acts, by contrast, cannot be expected for any type of interaction. Even if arguing is more or less cheap, that is of no relevance to the outcome of interaction, it is necessary to keep the conversation going. Moreover, arguing can be employed strategically. The presence of arguing speech acts alone thus does not tell us much about the publicity of interaction.

The second requirement for discursiveness, a dialogical rather than monological quality of interaction, can be assessed by drawing a further distinction between dialogical and non-dialogical arguing speech acts. Bargaining speech acts are always dialogical but not normally public in the required sense. A further subdivision within the category of bargaining speech acts is therefore not necessary for an assessment of discursiveness. Arguing, by contrast, can be either monological or dialogical, which is reflected on the level of illocutionary acts. Considering the list above, several items are intrinsically dialogical.

Not all speech acts occurring in natural conversation are captured within these lists. Further categories include rhetorical speech acts (e.g. rhetorical questions, quotations), discourse structurers (e.g. greetings, references to other speakers, meta-discourse), expressives and declarations (e.g. opening a meeting). Some of these types are typical for a specific form of interaction, such as rhetorical speech for public monologues. They were thus registered to further illustrate differences, although the assessment of discursiveness is based on the occurrence and proportion of dialogical arguing speech acts. 
Table 3. Arguing and bargaining speech acts

\begin{tabular}{ll}
\hline \hline Arguing speech acts & Bargaining speech acts \\
\hline CLAIM & to DEMAND/REQUEST \\
ESTABLISH & OFFER \\
ASSUME & SUGGEST (a compromise) \\
ASK & PROMOTE (an offer) \\
REPORT & ACCOMMODATE (a demand) \\
INFER & PROMISE \\
JUSTIFY/EXPLAIN & THREATEN \\
JUDGE & ACCEPT (an offer) \\
AFFIRM/ACCEPT (a claim) & REJECT (an offer) \\
CONTRADICT/CHALLENGE (a claim) & UPHOLD (a demand) \\
CONCEDE & CONCEDE (to a demand) \\
INSIST & ASCERTAIN CONSENSUS/NON-CONSENSUS \\
TAKE BACK (a claim) & \\
ASCERTAIN AGREEMENT/DISAGREEMENT & \\
\hline \hline
\end{tabular}

SAA is a very detailed analysis of linguistic interaction. A single contribution by a speaker in a conversation normally consists of a number of speech acts. In most cases, one sentence can be taken to represent one speech act. Sometimes a single word or a phrase constitutes a speech act, in other cases one speech act may carry on over several sentences. In pre-prepared speeches such as those held in the Bundestag, single speech acts are usually easy to identify. In spontaneous speech, by contrast, actors often start a sentence, hesitate, correct themselves, rephrase the initial sentence, repeat their utterance, so that we end up with several sentences for one speech act.

The data used for the SAA of the debate consists of the transcripts of the Bundestag's 214th session on 30 January 2002, which took about $3 \mathrm{~h}$ and $15 \mathrm{~min}$. From the available transcripts of the citizen conference, an excerpt of similar length from the second weekend meeting was chosen, in which citizens discuss which the most relevant aspects of the matter are. The excerpt does not include any prearranged expert presentations and initial organizational problems had already been resolved at this stage. The subject matter therefore comes closest to the Bundestag debate, and the mode of interaction closest to ideal-typical interaction. ${ }^{14}$

In the analysis of both the Bundestag's debate and the citizen conference, a record of the type and number of speech acts was compiled for every speaker. It may be argued that the isolation of speech acts and their classification into CLAIMING or REPORTING, ESTABLISHING, or ASSUMINGis to some extent subjective. This is why coding was carried out independently by two coders using the same list of types of speech acts and a codebook containing their definitions. The list of speech acts was

\footnotetext{
${ }^{14}$ During the first meeting organizational matters played a large role, and the third was dominated by the expert hearing.
} 
Table 4. Dialogical arguing speech acts (cf. Landwehr, 2009: 150)

Dialogical arguing speech acts

to ASK

INFER (from another speakers' assertions)

JUSTIFY

AFFIRM/ACCEPT (a claim)

CONTRADICT/CHALLENGE (a claim)

CONCEDE

INSIST (in face of challenges and counterarguments)

TAKE BACK (a claim)

jointly developed by the coders after the first explorative analysis of the material. Transcripts of the parliamentary debate were coded independently by the authors, transcripts of the citizen conference by Claudia Landwehr and Markus Lindner. For single contributions of speakers, there was a variance of between $10 \%$ and $15 \%$ between the coders. In the aggregation (where the total number of, e.g. arguing and bargaining speech acts was stated), variances mostly cancelled one another out, so that on the whole, there appears to have been no bias in any specific direction. Variances mostly concerned the number of speech acts of a specific type identified in a single contribution. The numbers given below are from the principal coding, the reliability of which was checked with the second coding. ${ }^{15}$

\section{Measuring preference change}

Preference changes can be inferred either from an actor's behaviour or from his reports in surveys or interviews. For the parliamentary debate, the roll call allowed us to make inferences from voting behaviour: it is simply assumed that those parliamentarians who voted for the same motion they had signed in advance had not changed their preferences. To those parliamentarians who did not sign any of the motions, a questionnaire was sent out.

For the citizen conference, a comprehensive evaluation by Henning and Erdwien (2004) is available. The entire event was extensively documented with tape and video recordings. Before the first and after each of the following meetings, participants filled in questionnaires on the atmosphere in the forum, on their evaluation of the procedure and on their own feelings and opinions. Answers to questions concerning their own knowledge about the matter and the comparative evaluation of arguments for and against ES cell research are indicative of preference changes. Moreover, the qualitative assessment of the conference by the direct observers addresses preference changes and their direction.

15 The text of the plenary debates can be obtained from the website of the German Bundestag, the transcript of the citizen conference is confidential. The coded data is available as an SPSS file at the following website: www.gesellschaftswissenschaften.uni-frankfurt.de/index.pl/clandwehr 


\section{Findings}

In what follows, we analyse first the discursiveness of both forums and second, their coordinativeness. In the last section, we look at the extent of preference transformation observed.

\section{Discursiveness}

The Bundestag plenary debate over ES cell imports was fully public, and more so than ordinary debates. Although all meetings of the Bundestag's plenum are accessible to the public, this one enjoyed particular attention, was broadcast live on television and analysed by a number of journalists. For the single speaker as well as for the institution as a whole, much reputation and esteem depended on their performance on this occasion.

Despite the high quality of argumentation, and in keeping with the ideal type mode of interaction, the debate in the Bundestag does not qualify as discursive according to the definition above. As the results of the SAA plainly demonstrate (see below), the debate falls short of the criterion of dialogical interaction. Apparently, the underlying logics of interaction and procedural requirements in this setting effectively prevented dialogue. Speaking time in the Bundestag is assigned according to the number of signatories for a motion, and the list of speakers determined in advance. This creates a division of the forum into speakers and listeners, for whom it is almost impossible to become speakers themselves - if not by means of interruption. Speakers have their contributions prepared in advance, and limited speaking times are rigorously enforced.

In the citizen conference, the organizers took pains to ensure both publicity and the dialogical quality of interaction in their choice of procedural details. A part of the conference, the expert hearing, was fully public and attended by a number of interested citizens. During the plenary meetings, an audience of observers as well as the tape recordings constituted publicity. The dialogical quality was enabled by the comparatively small size of the forum and encouraged by the moderators. The clear intention in procedural rules and the set-up of the forum was that each of the citizens should be at liberty to speak whenever they wanted to.

While these characteristics are more or less obvious at first glance, the idealtypical features of interaction are even more clearly reflected in the microanalysis of single speech acts. The following table displays the frequency of different types of speech acts in the debate and in deliberation.

In both cases, the effect of publicity on interaction is, at the illocutionary level, reflected in the dominance of argumentative speech acts. Arguing speech acts make up about three quarters of the total number of speech acts, although their percentage is higher in the debate. Bargaining speech acts account for only $2 \%$ here, but for $15 \%$ in deliberation. The publicity-oriented and justificatory nature of communication in the debate also explain the non-negligible number of purely rhetorical speech acts and expressives. 
Table 5. Types of speech acts in parliamentary debate and citizen conference

\begin{tabular}{lrrrrr}
\hline \hline & \multicolumn{2}{c}{ Parliament } & & \multicolumn{2}{c}{ Citizen conference $^{\mathrm{a}}$} \\
\cline { 2 - 3 } \cline { 5 - 6 } Type of speech act & Number & $\%$ & & Number & $\%$ \\
\hline Arguing & 1061 & 76 & & 636 & 70 \\
Bargaining & 32 & 2 & & 135 & 15 \\
Rhetoric & 41 & 3 & 1 & 0 \\
Discourse structurers & 226 & 16 & & 103 & 31 \\
Expressives & 36 & 0 & & 25 & 1 \\
Others & 0 & 100 & 908 & 100 \\
Total & 1396 & & & \\
\hline \hline
\end{tabular}

${ }^{\mathrm{a} C}$ Contributions from moderators and organizers are not included here.

With regard to the dialogical qualities of interaction, it is the proportion of specifically dialogical speech acts among the arguing speech acts that is of central relevance. With only $16 \%$, it accounts for less than a fifth of the total in the debate. That this percentage is strikingly small becomes apparent when comparing it with the result for the citizen conference, where more than half $(56 \%)$ of the arguing speech acts are dialogical.

The type of arguing speech acts dominant in the parliamentary debate are clearly 'to ASSERT' and 'to ESTABLISH'. ${ }^{16}$ Many contributions indeed consist merely in an enumeration of assertions. It is the very specific situation of a public monologue that makes this possible. In dialogical interaction, assertions can and will be challenged, and it is far more difficult to treat assumptions as taken for granted. The possibility of challenges is likely to deter speakers from controversial assertions unless they are able and willing to defend these.

A closer look at the types of dialogical speech acts that occur most frequently in each of the two forums is equally revealing. In the parliamentary debate, inferences and justifications are clearly dominant. In the citizen conference, a far higher percentage is made up by other dialogical speech acts. This indicates the product character of argumentation in the parliamentary debate in contrast to the process character of argumentation in the citizen conference. Although inferences and justifications can and should be counted as dialogical speech acts, they are equally constitutive of the product as of the process of argumentation. To ASK, INSIST, CONTRADICT, or AGREE, by contrast, are more typical for the process than for the product: they indicate where further justification is necessary. It should be noted, moreover, that the total number of justifications and inferences is much lower in the debate than in the citizen conference. Given the justificatory purpose

16 The distinction between the two is based on the assumption that assertions are claims which the speaker acknowledges to be still controversial while establishments presuppose agreement, that something is taken for granted (e.g. 'As we know...'; 'As has been shown...'). 
Table 6. Arguing speech acts in parliament and citizen conference

\begin{tabular}{lcccrr}
\hline \hline & \multicolumn{2}{c}{ Parliament } & & \multicolumn{2}{c}{ Citizen conference $^{\mathrm{a}}$} \\
\cline { 2 - 3 } \cline { 5 - 5 } Type of speech act & Number & $\%$ & & Number & $\%$ \\
\hline Dialogical & 169 & 16 & & 359 & 56 \\
Establish & 223 & 21 & & 140 & 8 \\
Assert & 500 & 47 & & 48 & 14 \\
Others & 169 & 16 & & 89 & 100 \\
Total & 1061 & 100 & & 636 & 22 \\
\hline \hline
\end{tabular}

${ }^{a}$ Contributions from moderators and organizers are not included here.

Table 7. Dialogical speech acts in parliament and citizen conference (cf. Landwehr, 2009: 174)

\begin{tabular}{lcccrr}
\hline \hline & \multicolumn{2}{c}{ Parliament } & & \multicolumn{2}{c}{ Citizen conference $^{\mathrm{a}}$} \\
\cline { 2 - 3 } Speech act & Number & $\%$ & & Number & $\%$ \\
\hline Ask & 0 & 0 & & 67 & 19 \\
Take back & 0 & 0 & & 1 & $<1$ \\
Insist & 1 & $<1$ & & 17 & 5 \\
Concede & 16 & 9 & & 6 & 2 \\
Contradict & 25 & 15 & & 66 & 18 \\
Agree & 11 & 7 & & 48 & 6 \\
Infer & 52 & 31 & & 22 & 37 \\
Justify & 64 & 37 & & 132 & \\
Total & 169 & & 359 & \\
\hline \hline
\end{tabular}

${ }^{a}$ Contributions from moderators and organizers are not included here.

of parliamentary communication, this seems surprising, but can be attributed to the fact that the direct challenge of assertions is not possible.

\section{Coordinativeness}

In plenary debates in parliamentary systems, and in particular in Germany, where the government always enjoys a safe majority, coordination seems neither possible nor necessary, as the majority coalition required for a decision already exists. ${ }^{17}$ Compared to the normal legislative procedures and plenary debates in the German parliament, the Bundestag's decision over the import of ES cells is surely an exceptional case. Party discipline was suspended to allow MPs to treat the

${ }^{17}$ In presidential systems, it must be noted, the debate as an ideal-typical mode of interaction is less likely to be institutionalized in the plenary meetings. Some kind of coordination will always be required there. 
decision as a matter of conscience. In contrast to the ordinary decisions, where experts within the parliamentary groups determine the way to go, this decision depended on the votes of lay parliamentarians, and is, in this respect, similar to the citizen conference. MPs were accordingly under intense pressure in the formation of their opinions and preferences, and subject to unusually high levels of public supervision. As most of them regarded the outcome of the decision as entirely open, MPs felt a particular institutional responsibility. It seemed that a very special moment was indeed required to accomplish the task of responsibly taking a decision on such a complex and important matter.

The Bundestag's debate over ES cell imports deviates from the ideal type in this respect. None of the three motions had a sufficient majority behind it, and only three quarters of the MPs had signed any one of the motions. To achieve an absolute majority, leaders of the three motions therefore still had to gain support for their option. Given the non-dialogical mode of interaction, however, it remains dubious whether, even under such very favourable conditions, the extent of coordination needed to form a majority is possible in the setting of a plenary debate.

In this particular debate, speakers were confronted with a dual task. On the one hand, they competed for the votes of members of the Bundestag who were still undecided and had signed none of the motions. On the other hand, and in spite of the fact that the vote was on motions rather than a bill, they had to fulfil the parliamentary task of justifying their decision to the public. For neither of these tasks was coordination, which would have necessitated compromises on practical reasons, required. The mode of plenary debates simply leaves no room for dialogue and compromise.

With regard to the citizen conference, at least three aspects may be expected to have significantly reduced the coordinativeness in comparison with the ideal-type of deliberation. One is the organizing committee's intention to reflect the plurality of opinions and values rather than actively pursue consensus, which is also indicated by the rejection of the 'consensus' label. Although the forum was modelled on Danish consensus conferences, the organizers preferred the moniker of 'citizen conference', which avoided the implication of unanimity, which in their opinion could not reflect social reality with regard to the matter of stem-cell research (ben Salem and Tannert, 2004: 106). The second factor to reduce coordinativeness was the fact that at the time the conference took place, the Bundestag had just taken a decision on the matter, so that any results produced by the citizen forum could not be immediately relevant to a political decision. Finally, participants had no material interest in the regulation of stem cell research, and particular emphasis was placed on the representativeness of the citizen group, which was to be ensured by a sophisticated system of random sampling. This opened up the opportunity for an easy and more or less cost-free exit, which constitutes a further caveat with regard to coordinativeness. Indeed, 5 out of 17 members had dropped out of this forum when the group presented its vote to the president of the Bundestag in March 2004. In sum, external pressures for coordination were not high. 
It is therefore interesting that coordinative bargaining speech acts are surprisingly frequent in the deliberation setting (see Table 5). Publicity was lower in the citizen conference than in the debate, which could in principle increase incentives for bargaining. Considering that participants had no material interests in the results of the procedure and that exit was easy, however, bargaining in the classical sense appears unlikely for this setting. Moreover, the percentage of arguing speech acts is only marginally higher in the debate than in the citizen conference, and bargaining does not seem to have impaired arguing. A closer look at the instances in which bargaining speech acts occur shows that they are found mainly in contexts of procedural meta-discourse. Bargaining speech acts appear when discussions turn to when to reassemble the next day, or whether to discuss a topic in small groups or in the plenum. Most of the bargaining speech acts are proposals or appeals, threats, or promises do not occur.

The transcripts show a more or less profound insecurity among both the organizers and the participants where the necessary degree of coordination is concerned. The organizers and moderators have an apparent (even material) interest in the success of the conference. Criteria for such a success are adherence to the time schedule, no or only a small number of drop-outs and, first and foremost, a presentable result in the form of a citizen vote. At the same time, they have to avoid any impression of authoritarianism or unjust influence on participants' opinions. On the citizens' side, the strong desire to learn and to do justice to all relevant aspects of the topic detracts attention from the goal of a joint (if not consensual) vote and report.

However, the group was quite perceptive of these problems and clearly had more ambitious goals for the conference than the organizers. Far from deeming it sufficient to reflect the well-known plurality of opinions and moral conflict, they regarded its results as an important input to political processes. Moreover, they recognized that only a clear majority or consensus was likely to give politicians reason to rethink their position. Both in questionnaires and in discussions, participants complained that too much time was consumed by the expert hearing and its preparation, time which could have been better used for the drafting of the vote - and thus for coordination. On the whole, it seems that dynamics within the citizen group countered the less than favourable external factors for coordination.

Judging from the non-consensual vote, the coordinative properties of the citizen conference do not appear too impressive. It must be taken into consideration, however, that the citizen group had little previous knowledge on ES cell research and most members were also unfamiliar with technical terminology. Accordingly, a large share of the time scheduled for the conference was used for information and the preparation of the expert hearing. Given the resulting shortage of time, the degree of coordination achieved is non-negligible. Moreover, not only is the consensual part of the report substantial, but agreement was also achieved on only seemingly procedural matters such as whom to invite and what questions to ask. 


\section{Preference transformation}

The ballot succeeding the debate on 30 January was a roll call vote, and all members had to attend the plenum and pass a vote that would then be registered alongside their name and constituency. About $75 \%$ of the members had signed one of the motions. One reason why some parliamentarians remained reluctant to sign one of the motions was that they were unwilling to vote against the majority of their own party. However, there were also a considerable number of undecided or uninformed members. As the 138 members who had signed neither motion could in principle swing the vote towards either the compromise or the ban, the outcome of the decision was regarded as more or less open. Accordingly, there seemed to be room for preference formation and transformation during the debate. At least with regard to stated preferences, the result of preference formation is available by virtue of the open ballot.

The clearest evidence for preference transformation in this setting would be the presence of parliamentarians who voted for a motion other than the one they had signed. Although such a decision could be based on pragmatic reasons (e.g. dynamics within the own party and new alliances), it could also indicate that exposition to new information was effective in changing their preferences, despite the otherwise unfavourable conditions. However, a look at the results of the open ballot quickly rebuts this possibility. With a single exception, none of the 460 members who had signed a motion voted for a different one in the first round. ${ }^{18}$

The attention consequently has to shift to those 138 members of the Bundestag who had not signed one of the motions. The speakers' attempts at persuasion were directed at these 'undecided' members rather than at the proponents of either of the other motions. Table 8 indicates that the number of those voting for the ban was particularly high among signatories while the number of those voting for the compromise motion was particularly high among the non-signatories. The first column states the number and percentage of all members who voted for each of the motions, the second the distribution of signatories among the motions, and the third the distribution of non-signatories. The rightmost column indicates the proportion of votes each of the motions gained or lost in the ballot in comparison with its number of signatories (i.e. it gives the difference between the percentage of votes of signatories and non-signatories for the respective motion).

Compared to the null hypothesis that the votes of non-signatories are equally distributed over the three motions, as the votes of signatories, the compromise motion clearly gains while the ban motion clearly loses (and the permit motion gains very little). Does this indicate that the debate has swayed preferences towards the compromise motion? Although this interpretation would be favourable with

\footnotetext{
18 This MP signed the compromise motion, but voted for the ban in the first round. In the second round, he voted for the compromise. Possible explanations are: he accidentally ticked the wrong box, he was convinced in informal conversations between the ballots, or he was unsettled by the debate but then regained confidence in his preference.
} 
Table 8 . Voting behaviour of signatories and non-signatories

\begin{tabular}{|c|c|c|c|c|c|c|c|}
\hline \multirow{2}{*}{$\begin{array}{l}\text { Members } \\
\text { Motion }\end{array}$} & \multicolumn{2}{|c|}{ Votes (all) } & \multicolumn{2}{|c|}{ Signatories } & \multicolumn{2}{|c|}{ Non-signatories } & \multirow{2}{*}{$\begin{array}{c}\text { Difference } \\
\%\end{array}$} \\
\hline & Number & $\%$ & Number & $\%$ & Number & $\%$ & \\
\hline Ban & 263 & 44 & 217 & 47 & 46 & 33 & -14 \\
\hline Compromise & 225 & 38 & 163 & 35 & 62 & 45 & +10 \\
\hline Permit & 106 & 18 & 80 & 17 & 26 & 19 & +2 \\
\hline Abstention & 4 & $<1$ & 0 & 0 & 4 & 3 & \\
\hline Total & 598 & 100 & 460 & 100 & 138 & 100 & \\
\hline
\end{tabular}

regard to the parliament's capability as a deliberative forum, and although it is supported by the champions of the compromise motion, plausible alternative explanations are available. One is that non-expert and undecided parliamentarians will tend to seek a middle way rather than adopt an extreme position on a topic they are unfamiliar with. The unexpected success of the compromise motion in comparison with the number of its signatories is thus only a very ambiguous indicator for preference transformation during the debate.

To find out more about the preference formation of those parliamentarians who had not signed one of the motions, a survey was undertaken. In anonymous questionnaires, they were asked about when they formed their opinion on the matter and how it was affected by the debate. Of the 138 'undecided' parliamentarians, $26(19 \%)$ sent back the questionnaire. Given that the decision over ES cell imports was nearly 4 years ago at this time, the low return rate is hardly surprising. ${ }^{19}$ The small number of respondents does not allow us to draw far-reaching conclusions from the survey.

There is only a single case of manifest preference transformation in the sample: one respondent indicates that, originally a supporter of a complete ban, she was persuaded to vote for the compromise motion. Seven respondents state that they know of a member who changed their preference during the debate, while 19 are not aware of preference changes. Of course, those who report they know someone who changed preferences could all be thinking of the same person. However, as they are distributed over governing and opposition parties, it is more likely that some of them know of different cases. Even then, however, the number of MPs who did change their preferences seems to be extremely small.

The analysis of deliberation in the consensus conference reveals a greater extent and different direction of preference transformation. A majority of the citizens confirm a strong expert influence on their opinion-formation (Henning and Erdwien, 2004: 64). Immediately after the hearing, about half of the citizens state that it has

\footnotetext{
19 To assess whether the sample is representative of the whole, participants were asked to state their sex and whether they belonged to the governing or opposition parties. The results show that respondents were disproportionately male and member of opposition parties.
} 
rendered them more sceptical (Ibid: 57). However, the citizens themselves selected the mostly critical experts, reflecting a critical tendency at an earlier stage. Moreover, transcripts indicate a certain development away from factual and towards ethical and political questions. One item in the questionnaire concerned the aspects participants deemed important for an evaluation of ES cell research. While in the control group, the ranking of relevant aspects remained stable between the dates for the first and third weekend (Ibid: 26), the ranking in the citizen group changes significantly over the three weekends (Ibid: 25). 'Ethical aspects' rank highest from the beginning, 'social aspects' lose out at first, but eventually gain in importance, and 'political aspects', which ranked very low on the first two weekends, gained in importance considerably on the last weekend. 'Health aspects', which were in second place on the first weekend, lost relevance to a significant degree in the citizens' opinion, similarly to 'economic aspects'. 'Religious aspects' ranked low from the beginning, whereas 'scientific aspects' were stable at a high level.

The change in the aspects considered relevant for the evaluation indicates changes in the weighting of practical reasons and hence preference transformation on the volitional, and not only the cognitive side. The fact that social and political aspects gained in importance compared to economic and health aspects suggests a politicisation of the forum. Although 'scientific aspects' remain important, the citizen group has apparently seen through the rhetoric of an 'ethic of healing', which among liberals in politics and the media often intentionally confuses the potential for a cure with the actual cure. Information on the factual state of research (no foreseeable application in the near future) as well as critical voices from patient representatives in the hearing induced a change in acceptances, and consequently in the weighting of practical reasons.

Taking the group as a whole and comparing it to the control group, it is not only apparent that preference transformation did take place and originated both on the volitional and the cognitive side, but also that preferences changed in a similar direction: contrary to the hopes of science politicians, citizens became more critical with regard to ES cell technology (Erdwien, 2004: 136).

\section{Conclusion}

Our theoretical considerations dealt with a central assumption in the theory of deliberative democracy, namely that deliberation enables preference transformation and that other modes of political interaction, in this case the debate, fail to do so. In our empirical illustration, neither the Bundestag debate and nor the citizen conference on ES cell imports appear to have been perfect institutionalizations of debate and deliberation as ideal-type modes of interaction. The parliamentary setting seems to have been far more favourable to coordination than the ideal-type debate. The citizen conference was, while fully discursive, less coordinative than ideal-type deliberation. Nevertheless, the predictions on modes of interaction and on preference transformation hold for these cases. There was almost no preference 
transformation in the parliament, while there was a substantive amount in the citizen conference.

We come to the conclusion that the forum that is traditionally seen as an institutionalization of deliberation - the plenary session in parliamentary democracy - tends to rule out both deliberation as a dominant mode of interaction (at least as we define it) and preference transformation. This is not to say that plenary debates do not play an important role in democracies. Instead, the different and complementary roles of different modes of interaction in decisionmaking processes need to be appreciated (see Mansbridge, 2006).

What we have in mind here is a deliberative system in which deliberation can be distributed, decentralized, and iterated (Thompson, 2008: 214-215; Goodin, 2005). Deliberation is not necessarily the most desirable mode of interaction that should replace all other modes. All four of the modes we defined above play essential roles. In less ideal cases, discussion, bargaining, and debate can also substitute deliberation to some extent. A decision that is informed by expert discussions will often be better than one that is not so, and a decision arrived at through tough bargaining is in many cases better than no decision at all. The parliamentary debate in particular, although it is neither discursive nor coordinative according to our definition, provides an important kind of substitute. While it displays a product rather than a process of argumentation, it can offer reasons and justification and assist citizens in the formation of political preferences. As Jürgen Habermas points out, its 'out-of-door reference to a larger audience serves the function of mobilizing and securing legitimation for one's party and is, normatively speaking, quite in order, even though it lowers the kind and quality of deliberation.' (Habermas, 2005: 390)

One of the tasks for deliberative democrats is accordingly to inform institutional design in order to ensure that institutions and decision-making practices are chosen deliberatively and deliberatively justified (Thompson, 2008: 515; see also Gutmann and Thompson, 1996). Given that deliberation is notoriously difficult to institutionalize, it may be necessary to pay more attention to the role of informal citizen conversations about politics and to the relations between media debates, public opinion, and formal institutions. However, participatory procedures can play an important role in the vitalization of democracy and should by no means be given up.

With regard to future empirical research, we think that there is a need for a systematic comparison of different forums dealing with the same conflict, and of forums of the same type dealing with different conflicts. ${ }^{20}$ If we want to find out more about how deliberation can best be institutionalized, we need cases where institutional characteristics form the independent variable and where other variables that affect outcomes of interaction are as constant as possible. Many experimental

${ }^{20}$ A recent paper by Hendriks et al. (2007) constitutes a notable approach in this direction. 
approaches, while surely valuable in themselves, are isolated studies of one-off events that lack this kind of variation and therefore fall short of realizing their full potential. Comparing citizen forums with different set-ups with regard to the mode of interaction, the amount of preference transformation, and the policy recommendations they produce is thus an important research desideratum.

\section{Acknowledgements}

We thank the participants at the ECPR workshop on 'Empirical approaches to deliberative democracy' in Helsinki in April 2007, in particular Albert Weale, John Dryzek, and André Bächtiger, as well as three anonymous reviewers for the EPSR for valuable comments on earlier versions of this paper, and the Max-Delbrück-Center Berlin for allowing us to use transcripts of the citizen conference on stem cell research.

\section{References}

Austin, J.L. (2002 [1962]), Zur Theorie der Sprechakte (How to Do Things with Words), Leipzig: Reclam.

Bächtiger, A. (2005), The Real World of Deliberation. A Comparative Study of its Favorable Conditions in Legislatures, Bern: Paul Haupt.

Bächtiger, A., S. Niemeyer, M. Neblo, M.R. Steenbergen and J. Steiner (2010), 'Disentangling diversity in deliberative democracy: competing theories, their empirical blind-spots, and complementarities', Journal of Political Philosophy 18(1): 32-63.

ben Salem, A. and C. Tannert (2004), 'Planung und Organisation der Bürgerkonferenz', in C. Tannert and P. Wiedemann (eds), Stammzellen im Diskurs, München: Oekom, pp. 106-116.

Bessette, J.M. (1980), 'Deliberative democracy: the majority principle in republican government', in R.A.S. Goldwin and A. William (eds), How Democratic is the Constitution?, Washington: AEI, pp. 102-116.

Bohman, J. (1996), Public Deliberation. Pluralism, Complexity, and Democracy, Cambridge, Massachusetts: MIT Press.

Bohman, J. and W. Rehg (1997), Deliberative Democracy, Cambridge, Massachusetts: MIT Press.

Brandom, R.B. (1994), Making it Explicit. Reasoning, Representing, and Discursive Commitment, Cambridge, Massachusetts: Harvard University Press.

Burow, O.-A. and K. Kühnemuth (2004), 'Brauchen Wissenschaft und Politik Bürgerberatung? Möglichkeiten und Grenzen der Bürgerkonferenz', in C. Tannert and P. Wiedemann (eds), Stammzellen im Diskurs, Müchen: Oekom, pp. 117-129.

Chambers, S. (2004), 'Behind closed doors: publicity, secrecy, and the quality of deliberation', The Journal of Political Philosophy 12(4): 389-410.

- (2005), 'Measuring publicity's effect: reconciling empirical research and normative theory', Acta Politica 40: 255-266.

Cohen, L.J. (1989), 'Belief and acceptance', Mind xcviii(391): 367-389.

della Porta, D. (2005), 'Deliberation in movement: why and how to study deliberative democracy and social movements', Acta Politica 40: 336-350.

Dryzek, J. (2000), Deliberative Democracy and Beyond, Oxford: OUP.

Elster, J. (1995), 'Strategic uses of argument', in K. Arrow (ed.), Barriers to Conflict Resolution, New York: W.W. Norton \& Co, pp. 236-257.

- (1998), 'Deliberation and constitution making', in J. Elster (ed.), Deliberative Democracy, Cambridge: Cambridge University Press, pp. 97-122. 
Erdwien, B. (2004), 'Bürgerpartizipation als Gruppenprozess: Ergebnisse der begleitenden Evaluation', in C. Tannert and P. Wiedemann (eds), Stammzellen im Diskurs, München: Oekom, pp. 130-137.

Fishkin, J. (1991), The Voice of the People: Public Opinion and Democracy, New Haven: Yale University Press.

Fishkin, J.S. and P. Laslett (eds) (2003), Debating Deliberative Democracy, Malden, Massachusetts: Blackwell.

Gastil, J. and P. Levine (eds) (2005), The Deliberative Democracy Handbook, San Francisco: Jossey-Bass.

Goodin, R.E. (2003), Reflective Democracy, Oxford: OUP.

— (2005), 'Sequencing deliberative moments', Acta Politica 40: 182-196.

Gutmann, A. and D. Thompson (1996), Democracy and Disagreement, Cambridge, Massachusetts: Belknap Press.

Habermas, J. (1984), The Theory of Communicative Action, Boston: Beacon Press.

- (1994), Faktizität und Geltung, Frankfurt a. M.: Suhrkamp (English translation: Between Facts and Norms, Cambridge: MIT Press).

- (2000), 'From Kant to Hegel: on Robert Brandom's pragmatic philosophy of language', European Journal of Philosophy 8(3): 322-355.

- (2005), 'Concluding comments on empirical approaches to deliberative politics', Acta Politica 40: 384-392.

Hansen, K.M. (2004), Deliberative Democracy and Opinion Formation, Odense: University Press of Southern Denmark.

Harsanyi, J.C. (1955), 'Cardinal welfare, individualistic ethics, and interpersonal comparisons of utility', Journal of Political Economy 63(4): 309-321.

Hendriks, C.M., J.S. Dryzek and C. Hunold (2007), 'Turning up the heat: partisanship in democratic innovation', Political Studies 55(2): 362-383.

Henning, H.J. and B. Erdwien (2004). Bürgerkonferenz zur Stammzellforschung 2003/2004, Abschlussbericht. Bremen, Universität Bremen, Institut für Psychologie: 1-94.

Holzinger, K. (2001), 'Verhandeln statt Argumentieren oder Verhandeln durch Argumentieren? Eine empirische Analyse auf der Basis der Sprechakttheorie', PVS 42(3): 414-446.

- (2004), 'Bargaining through arguing: an empirical analysis based on speech act theory', Political Communication 21: 195-222.

- (2005), 'Context or conflict types: which determines the selection of communication mode', Acta Politica 40(2): 239-254.

Joss, S. and J. Durant (eds) (1995), Public Participation in Science. The Role of Consensus Conferences in Europe, London: Science Museum.

Landwehr, C. (2009), Political Conflict and Political Preferences. Communicative Interaction between Facts, Norms and Interests, Colchester: ECPR Press.

Macedo, S.E. (1999), Deliberative Politics. Essays on 'Democracy and Disagreement', Oxford: Oxford University Press.

Mansbridge, J. (2006), 'Conflict and self-interest in deliberation', in S. Besson and J.L. Martí (eds), Deliberative Democracy and its Discontents, Aldershot: Ashgate, pp. 107-132.

March, J.G. and J.P. Olsen (1989), Rediscovering Institutions. The Organizational Basis of Politics, New York: The Free Press.

Mutz, D.C. (2008), 'Is deliberative democracy a falsifiable theory?', Annual Review of Political Science 11: 521-538.

Naurin, D. (2007), Deliberation behind Closed Doors, Colchester: ECPR Press.

Neblo, M.A. (2005), 'Thinking through democracy: between the theory and practice of deliberative politics', Acta Politica 40: 169-181.

Niemeyer, S. (2002). Deliberation in the wilderness. Transforming policy preferences through discourse. Phd thesis. Australian National University.

Nullmeier, F. (2003), 'Sprechakttheorie und Textanalyse', in M.L. Maier, A. Hurrelmann, F. Nullmeier, T. Pritzlaff and A. Wiesner (eds), Politik als Lernprozess?, Opladen: Leske+Budrich, pp. 211-223.

Richardson, H.S. (1994), Practical Reasoning about Final Ends, Cambridge: Cambridge University Press. 
Scharpf, F.W. (1997), Games Real Actors Play. Actor-Centered Institutionalism in Policy Research, Boulder, Colorado: Westview Press.

Schneiderhan, E. and S. Khan (2008), 'Reasons and inclusion. The foundation of deliberation', Sociological Theory 26: 1-24.

Searle, J.R. (1979), 'A taxonomy of illocutionary acts', in J.R. Searle (ed.), Expression and Meaning. Studies in the Theory of Speech Acts, Cambridge: Cambridge University Press, pp. 1-39.

Steedman, I. and U. Krause (1986), 'Goethe's Faust and Arrow's possibility theorem', in J. Elster (ed.), The Multiple Self, Cambridge: Cambridge University Press, pp. 179-231.

Steenbergen, M.R., A. Bächtiger, M. Sporndli and J. Steiner (2003), 'Measuring political deliberation. A discourse quality index', Comparative European Politics 1: 21-48.

Steiner, J. and A. Bächtiger, et al. (2005), Deliberative Politics in Action, Cambridge: Cambridge University Press.

Sunstein, C.R. (2003), 'The law of group polarization', in J.S. Fishkin and P. Laslett (eds), Debating Deliberative Democracy, Malden, Massachusetts: Blackwell, pp. 80-101.

Tannert, C. and P. Wiedemann (eds) (2004), Stammzellen im Diskurs. Ein Lese- und Arbeitsbuch zu einer Bürgerkonferenz, München: Oekom.

Thompson, D.F. (2008), 'Deliberative democratic theory and empirical political science', Annual Review of Political Science 11: 497-520. 